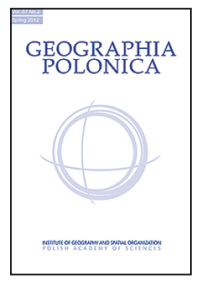

\author{
APAN \\ IGiP \\ (yilthe \\ INSTITUTE OF GEOGRAPHY AND SPATIAL ORGANIZATION \\ POLISH ACADEMY OF SCIENCES \\ www.igipz.pan.pl \\ www.geographiapolonica.pl
}

\title{
IS THERE A PLACE FOR BIOINDICATION IN THE GEOGRAPHICAL SCIENCES? A FOCUS ON TWO GROUPS (CARABIDAE AND ARANEAE)
}

\author{
Edyta Regulska \\ Institute of Geography and Spatial Organization \\ Polish Academy of Sciences \\ Twarda 51/55, 00-818 Warsaw: Poland \\ e-mail: eregulska@twarda.pan.pl
}

\begin{abstract}
This paper is a brief review of the current state of Carabidae and Araneae usefulness in indicator-based, geographical science studies. The database of scientific papers on the ISI Web of Science (Elsevier and Springer) was the main source of information. Only papers that considered landscape and addressed human activity in relation to selected taxa were chosen for further analyses. The articles with an explicit ecological character and which showed no potential possibilities for wider application in geographical research were not used. The selected papers were examined with respect to: the leading subject matter, area considered, applications, repetitiveness of the data collecting, and with respect to the aboveground and underground compartments. For clarity's sake, areas of land cover, land use, and human management were divided into four categories. The categories were ordered from 1 to 4 , according to increasingly human-induced pressure starting with (1) areas of a natural state, (2) proceeding to forests, (3) farm land, and (4) finally to urban/suburban. This non-exhaustive review confirms the very broad possibilities of applying selected taxa as indicators in geographical studies. Such an application refers to both the range of possibilities of the study location choice (forest, arable, suburban areas etc.), and the subject matter of the study. Faunistic indicators can supply geographical researchers with quantitative and qualitative data. The data then allow for an estimation of the ecological response, due to the variety of changes taking place in the ecosystem. Faunistic indicators are invaluable tools for indirectly estimating subtle environmental changes. Such changes include those which are the result of a specific interaction between ecosystem components, which are difficult to measure using traditional methods. The impact of human activities can thus be assessed in a much more cost-effective way. A key methodological aspect is to choose the most accurate faunistic groups for the study as well as using standardised method of collecting. It is also important to consider the environmental parameters which have an impact on the selected bioindicators.
\end{abstract}

\section{Key words}

bioindication - land use - habitat variables - Carabidae - Araneae 


\section{Introduction}

According to Richling (1983: 185) "complex physical geography (landscape geography) is a science of the structure of the natural environment treated as a whole composed of interconnected and interacting components". In response to the increasing magnitude of human-induced environmental problems, many researchers are estimating how humans modify the environment. Such studies include: environmental degradation of the hydrosphere, atmosphere, lithosphere, and biosphere. Other studies cover: resource-use issues, natural hazards, environmental impact assessment, and the effect of urbanisation and land-use change on natural environments (Pidwirny 2006). Physical geography should not be reduced to only being a science that defines e.g. a type of soil or landscape structure. Physical geography should consider the environment as a whole. Particular attention should be given to the effects of human activity. In physical geography, bioindicators can be adequate for measuring subtle environmental changes resulting in a specific interaction between ecosystem components. This refers to components which are difficult to measure by traditional methods. An assessment of the impact of human activities in a much more cost-effective way, is also important. Paoletti (1999) defined bioindicator as a species or assemblage of species that is particularly well-matched to specific features of the landscape and/or reacts to impacts and changes. In bioindicator-based research the living components of the environment are used as tools to estimate transformations and effects. In the case of landscape reclamation, the living components are used to monitor the remediation process in different parts of the landscape.

In recent years, there have been many papers on geobotanical and soil indicators (Roo-Zielińska et al. 2007; Richling \& Solon 2011). The number of scientific papers using different groups of animals in the landscape evaluation has also significantly increased. These papers are based on well-founded knowledge of the animals' physiological and behavioural responses to changes in environmental health. There have been changes in species composition (including the replacement of native species by exotic ones), quantitative changes (ecological groups, structure of domination, age structure, total number or species diversity, etc.) and changes in individual features (such as biomass or modification of body size).

Taking the field of interest of physical geography into account, good environmental bioindicators should be: (1) common and wide-spread in regard to the geographic distribution, (2) abundant in species of different dispersal abilities - mobile and less mobile species which present high spatial resolution data, (3) easy to collect and mark at the species level, (4) quickly react to human-induced environmental changes in ways that could be observed and quantified, and (5) show relatively low variance for the mean number of individuals collected at one site and a high degree of habitat preference for the habitat considered (Perner \& Malt 2003). Spiders (Araneae) and ground beetles (Carabidae) fulfil these criteria. They are specifically recognised environmental bioindicators (Büchs 2003; Büchs et al. 2003; Heyer et al. 2003; Pearce \& Venier 2006). Both play a major ecological role as generalist predators of smaller arthropods in most terrestrial food webs (Marc et al. 1999) and in forages for vertebrates (Deichsel 2006). Spiders are obligate predators, while ground beetles are predominately predators or omnivores.

According to the Polish scientific literature, spiders and carabids as indicators are mostly used in studies on forest environment processes (especially in those studies from the Department of Forest Protection and Ecology Warsaw University of Life Sciences - SGGW in Warsaw). However, many other Polish authors have found new information about species diversity in relation to a particular crop, soil or habitat type (e.g. Stańska et al. 2002; Huruk 2005, 2007; Aleksandrowicz et al. 2008; Kosewska et al. 2011). For this reason, this brief literature review was based mainly on scientific articles from the ISI Web of Sci- 
ence (publishing house Elsevier and Springer). From the database, those articles selected fulfilled the following criteria: (1) a time period that was from between 1989 and 2013, (2) keywords 'Carabidae'/'Araneae' and 'indicator' were used in the abstract, keywords, and the text of the article, and (3) the articles were written in English. After screening the abstracts, those papers that considered landscape and addressed human activity in relation to selected taxa, were chosen for further analyses. The articles of an explicitly ecological character, e.g. on the effects of GMO (Genetically Modified Organisms) crops, were not used. The selected papers were examined with respect to the leading subject matter, the area considered, applications, repetitiveness of the data collecting, and aboveground and underground compartments. Finally, the review included only those studies which showed potential possibilities for a wider application in geographical research (quite different from the already published reviews e.g. Rainio \& Niemelä 2003; Pearce \& Venier 2006; Koivula 2011).

The articles took into consideration land cover, land use, and human management. For better clarity, four division were made and ordered according to increasingly human-induced pressure starting with (1) natural areas, (2) forests, and (3) farm lands to (4) urban/suburban. The natural areas division refers to studies carried out mostly in non-forested areas with an addition of natural and semi-natural vegetation including wetlands and heathland complexes. The forest division also contains strongly transformed forest areas, such as tree plantations. The farm land division includes meadows and pastures under strong human control, whilst the urban/ suburban also encompasses brownfields.

\section{Results of the analysis of divisions}

\section{The natural areas}

Ground beetles are accurate indicators of the state of natural and semi-natural environments. Such states include the appraisal of habitat restoration (Watts et al. 2008), an assessment of the concentration and distribution of heavy metal contamination in the soil and in living organisms (Schipper et al. 2008), and the concentration of elements, such as nitrogen, e.g. over the moorlands (Cuesta et al. 2008).

Spiders are valuable 'tools' for monitoring studies. In these studies changes can be traced in: vegetation structure (Schikora 1994), hydrological conditions (Gravesen 2000), salinity and water level changes (Desender \& Maelfait 1999; Irmler et al. 2002) as well as human pressure (Maelfait \& Hendrickx 1997; Kajak et al. 2000) - especially where the conversion of natural areas into arable areas are concerned (Opatovsky et al. 2010). Spiders in natural areas can be used to indicate part of the 'biodiversity quality', to establish biodiversity change or stability (Feest \& Cardoso 2012), and to identify the drivers of succession after burning (Malumbres-Olarte et al. 2013).

In the natural areas group, analysis of the interrelations of the selected taxa with the habitat variables were accompanied by the analyses of other interdependences, concerning: (a) climatic parameters - monthly and/ or annual averages of precipitation and temperature, (b) soil parameters - acidity, soil organic carbon, total nitrogen content, ratio $\mathrm{C} / \mathrm{N}$, humidity and soil texture, (c) vegetation species of vascular plants, biomass, height, (d) other organisms - rove beetles, heteroptera, springtails, hymenoptera, diptera, and (e) landscape metrics - landscape composition, structure of boundaries and average field area.

\section{The forest}

In the forest category, Carabidae act as indicators to assess:

- methods of forest management (Butterfield et al. 1995; Beaudry et al. 1997; Werner \& Raffa 2000), different forest practices, e.g. felling, burning, grazing (Niemelä et al. 1993; Atlegrim et al. 1997; Taboada et al. 2006), and variable retention harvesting practices (Pinzon et al. 2012); 
- forest structure change - replacement of domestic species by other tree species (Yu et al. 2006; Wiezik et al. 2007), re-forestation using domestic tree species and observing the changes depending on the succession stage (Paquin 2008; Taboada et al. 2008), forestation of former agricultural areas (Szujecki et al. 1983), along with spatial isolation analysis (Grimbacher \& Catterall 2007), forest fragmentation e.g. after extraction of wood material (Davies \& Margules 1998; Pihlaja et al. 2006; Pohl et al. 2007);

- the forest condition - valorisation (Szujecki 2001), regressive changes and ecosystem regeneration after abrupt natural phenomena, such as wind breaks, hurricanes (Gandhi et al. 2008; Mądrzejowska \& Skłodowski 2008; Skłodowski \& Garbalińska 2011), and fires (Moretti et al. 2002; Buddle et al. 2006);

- the transfer of pollution in the soil and litter (Jelaska et al. 2007).

Spiders are most frequently regarded as relevant bioindicators of changes occurring in forests. These changes include the rates and directions of restoration of forest phytocoenoses on former agricultural land (Łęgowski 2000) as well as structure change, e.g. after fragmentation (Davies \& Margules 1998) and the resultant edge effect (Magura 2002; Pearce et al. 2005), and after fire and tree felling (Brennan et al. 2006; Larrivèe et al. 2008). Moreover, spiders are also a valuable 'tool' in forest valuation (Łęgowski 2001), and when noting the various stages of the forest plantation cycles. Spiders also have an impact on biodiversity assessment (Oxbrough et al. 2005), and on the estimation of the various forms of forest management, e.g. different retention harvesting practices such as green-tree retention and clear cutting (Matveinen-Huju et al. 2009).

In most of cases, the analysis of the relation among selected assemblages and the habitat variables mentioned, are in parallel with the analysis of other interrelations. The parameters most often used to characterise the environment were: (a) climatic and (b) soil - as in the natural group, (c) bedding structure - type and thickness of the litter layer, wood rests, dead wood, uncovered soil, (d) vegetation - structure of the herb layer, species composition, coverage and height of mosses, vascular plants, bushes and trees, compactness of tree canopies, height and circumference of trees as well as forest age, (e) other organisms - microorganisms, nematodes, mites, ants, springtails, rove beetles, enchytraeids, heteroptera, hymenoptera, diptera, and daddy-long-legs, (f) landscape metrics - distance to the forest edge, degree of isolation of the patches.

\section{The farm lands}

In the arable division, there was a noticeable domination of articles concerning ground beetles as indicators of:

- the manner of cultivating crops - organic or conventional (Kromp 1990; Hole et al. 2005; Birkhofer et al. 2008);

- the effects of agricultural intensification and extensification, including conversion of grassland to arable land and vice versa, increased and decreased levels of mineral fertilisation, and monoculture compared to crop rotation conversion of an extensively managed grassland to arable land (Postma-Blaauw et al. 2010, 2012);

- farming practices - intensity of treatment (Eyre et al. 1989) and their type, e.g. fertiliser use, grazing (Gibson et al. 1992; Grandchamp et al. 2005; Gudleifsson 2005; Kovács-Hostyánszki et al. 2013) or application of chemicals (Rushton et al. 1989; Thomson \& Hoffmann 2006; Frampton \& van den Brink 2007);

- biodiversity, especially in comparison with semi-natural areas (Duelli \& Obrist 1998) - studies on the effects of landscape structure on biodiversity: the role of midfield balks and strips (natural or sown) depending on the distance of the balks and strips from the field edge (Debras et al. 2008; Diekötter et al. 2008), the composition of the balks and strips (Woodcock et al. 2005), and the age of the balks and strips 
(Olechowicz 2004; Frank et al. 2007; Roarty \& Schmidt 2013).

Spiders, in farm land groups, are considered to be appropriate indicators of the management practises and management intensity (Kovács-Hostyánszki et al. 2013; Wickings \& Grandy 2013). These include the comparison with semi-natural areas (Cole et al. 2005), the introduction of forest plantations in previous fields (Oxbrough et al. 2006), the grazing effect (Gibson et al. 1992; Churchill 1998) and use of pesticides (Everts et al. 1989), landscape structure, the role of shelterbelts in adjacent fields, the distance to the wood boundary and the age of the tree stand (Kajak \& Oleszczuk 2004), of biodiversity (Marc et al. 1999), and in maintenance goals (Cardoso et al. 2004).

In the farm lands group, like all of the other above-mentioned groups, there were other interdependences: (a) climatic and (b) soil - as in natural group, (c) vegetation parameters - species of vascular plants, their biomass, height, existence, composition in fields and edges of fields, as well root biomass, (d) other organisms - microorganisms, nematodes, mites, ants, springtails, rove beetles, enchytraeids, heteroptera, hymenoptera and diptera, (e) landscape metrics - landscape composition, structure of boundaries and average field area.

\section{The urban/suburban}

In the urban/suburban group, Carabidae and Araneae are mainly used to assess the degree of urbanisation (Deichsel 2006; Elek \& Lövei 2007), to assess the degree of pollution with heavy metals (Nahmani et al. 2006; Hartley et al. 2008; Otter et al. 2013), to assess the radiation level (Møller \& Mousseau 2011), and to estimate local biodiversity (Angold et al. 2006).

As in the groups previously commented on, the analysis also included relations with: (a) climate - usually the same as above groups, (b) soil - as in the natural group, and $\mathrm{Zn}, \mathrm{Cd}, \mathrm{Pb}, \mathrm{Cu}$ ), (c) vegetation and bedding structure - species composition, coverage, and height of mosses, vascular plants, bushes and trees, thickness of the litter layer, wood rests, (d) other organisms - microorganisms, ants, rove beetles, birds, and small mammals, and (e) landscape metrics - magnitude of patches, distance to the forest edge, degree of isolation of the edges.

Besides the selected divisions, those studies using animals often took into consideration the gradients (e.g. pollution, human impact), and the deliberate crossings of different types of ecosystems. In such research studies, Carabidae were usually used to find out the impact of the intensity of various parameters on the environment. These parameters include salinity (Pétillon et al. 2008), humidity (Pardo et al. 2008), and the edge effect (Magura et al. 2001). They were applied as indicators of different types of agricultural and post-agricultural area management while additionally considering surrounding habitats, including forests, grasslands, fallow land, and agricultural fields (Błaszkiewicz \& Schwerk 2013). Carabidae were also used as indicators of carbon sequestration and in valuable landscapes (Szyszko et al. 2011). Spiders acted as indicators of biodiversity (Jung et al. 2008), vulnerability of systems for monitoring and maintenance (Cameron et al. 2004), and as indicators of the impact of long-term land use (Callaham et al. 2006).

\section{The scale of the study and repetitiveness of data collecting}

The majority of the articles concerned work carried out at more than one plot but within a single region. The next group concerned studies done only at single plots. Articles concerning multiple plots, in more than one region, were the fewest. The year-round collection of information was predominantly adopted. By definition, it encompassed at least two seasons: e.g. Spring and Autumn. The year-round collection of information fell into two groups. Either the year-round collection of information was done in a single season or the data were collected for a period of more than one year. 


\section{Discussion}

Studies in which Carabidae and Araneae were involved, had a dichotomous character. They were studies on interdependences, about what has an impact on the organisms and in what manner the impact is reflected. Most of the studies, though, addressed the cognition of interdependences with identification of bioindication mechanisms. This dichotomous character was also present in the studies that dealt with the valuation/indication of the selected aspects of the environment where Carabidae and Araneae were present. There were definitely more articles concerning selected taxa as indicators of environmental risk assessment. These numerous articles were about the monitoring of selected taxa responses to land use, different ways of management, landscape structure, and contaminations. More possibilities are described in the specified divisions.

Although not included in the "Results" section, it is worth adding that in studies connected with pollution, the accumulation of the respective elements in the soil, and the accumulation in living organisms was the most frequently applied descriptive parameter. Body length, sex, and scarcity of appearance were less commonly described. The measurement of body dimensions and size distribution of the species present in a habitat, is based on the assumption that changes in body size potentially indicate different types of environmental stress (McGeoch 1998). Body length (or indexes established on the basis of it Skłodowski 1995, 1997; Szyszko 1997; Cárdenas \& Hidalgo 2007) was especially used for Carabidae, assuming that larger species tend to be more sensitive to the disturbances in the environment than smaller ones. There were studies with the simultaneous use of many various groups of organisms. To simplify the technique of data collection and to decrease the time consumed by data processing, individuals were often assigned to higher taxa as families or orders.

Considerable variation exists in the spatial and temporal scale at which comparisons are made. This is a very important aspect, as single-time-instant studies - through temporal limitation, may reflect only a momentary response to the disturbing stress. Moreover, biota abundances and community composition vary over seasons and years (Dmowska 2007; Huruk 2007; Price \& Voroney 2008). However, despite temporal variation, the direction of change in the quantitative parameters of assemblages (reflecting e.g. human pressure) is usually consistent. As the main purpose of indication is not to describe the whole richness of a species, a short-term collection of data should be tested and developed. Cardoso et al. (2007) maintained that the end of May to early June is an appropriate time for collecting spiders in Mediterranean habitats if the objective is to do short-term intensive sampling. Presumably, in temperate climates, which are characterised by long winters, the beginning of May to the end of September are the best for sampling spiders as far as bioindication purposes are concerned.

Probably there is no species or group of species that would have all the properties of a good indicator. An important criterion for choosing the appropriate indicators is the fast and predictable response to disturbance or change in the environmental state in ways that can be readily observed and quantified. Moreover, indicators should be accessible for monitoring, and the indicators should be representative of their taxonomic or functional group. Both selected taxa fulfil these demands. Many taxa differ in their sensitivity to environmental change and habitat requirements, so some taxonomic groups may be affected more than others. An appropriate solution is to select a set of different taxa for indication purposes. A key methodological aspect is to choose the most accurate faunistic groups and the traits of the groups, for the particular study. The traits that characterise the ecological function of a species are termed functional traits. The species that share similar sets of traits are often categorised together into functional groups (Cleland 2012). A trait can be considered as any 
single feature or quantifiable characteristics of an organism, e.g. body size or wing development (size and dispersal traits) but also food and habitat preferences or the reproduction time period, and activity (ecological and life-history traits). Recent studies emphasise the use of ecological groups as a complementary approach reflecting ecological integrity (Regulska 2011). Responses to the environmental changes are often variable among species within groups, making general predictions difficult. The approach of the ecological groups provides an alternative understanding of how communities are organised and how they function. Such an approach allows for greater insight into community responses rather than simply stating the changes in species richness or taxonomic diversity (Driscoll \& Weir 2005; Schweiger et al. 2005; Vandewalle et al. 2010). The functional approach, especially due to the possible applications in various scales, was an important aspect of the many national and international programs, e.g. Soil Biological Site Classification - BBSK in Germany (Breure et al. 2005), Biological Indicator of Soil Quality - BISQ in the Netherlands (Römbke \& Breure 2005), The Estonian National Landscape Monitoring Programme (Sepp et al. 2005; Ivask et al. 2007), National Bioindicator Programme in France (Pérès et al. 2011), and the international project called Biodiversity Indicators for Organic and Low Input Farming Systems - Project Bio-Bio (2013).

It is also important to consider the environmental parameters which have an impact on selected bioindicators. When taking into consideration the soil parameters in the scientific papers, the most often included were: humidity, acidity, organic matter as well as carbon and nitrogen content. Much attention was paid to the vegetation structure (herb layer species composition, cover and height of mosses, vascular plants, bushes, trees) and, especially in the forests, to bedding structure (type and thickness of the litter layer, wood rests, uncovered soil). The most often applied landscape metrics were: landscape composition structure of boundaries, magnitude of the patches, distances between the patches, isolation of the patches, and distance from the edges. Results of the investigation show that studies with aboveground/ mobile fauna (Carabidae and Araneae) tend to be carried out on the broader landscape structure context than on the field/plot-scale. This is mainly due to aboveground/mobile fauna distinct perception of landscape dimensions than belowground/less mobile fauna (e.g. Lumbricidae) and less association with soil. Furthermore, within each of the thematic groups, other groups of organisms were used (especially: microorganisms, rove beetles, springtails, enchytraeids, and ants). The use of these additional organisms significantly broadened the field of investigation. The possibility of comparing the bioindicators, and allowing for the acquisition of information on the interactions taking place in the ecosystem, was increased.

Our brief review confirms the very broad possibilities of applying Carabidae and Araneae as indicators in geographical studies, both in terms of the range of the study location choice and the subject matter of the study. Complex physical geography studies are carried out at various spatial and temporal levels. The discussed indicators can be employed at a range of scales: from the singular field to the broader landscape level. These indicators can be appropriate in a one-season survey (e.g. single soil parameters measurement) as well as in a long periodical survey (changes in land management and land cover). Carabidae and Araneae can act as indicators in various habitats from natural, and semi-natural to habitats strongly controlled by humans, like arable land or urban areas. Although the use of bioindicators is substantially different from the use of traditional environmental measures, the use of bioindicators offers many benefits. Faunistic indicators can enrich and complement geographical research. Quantitative and qualitative data can be used for the estimation of ecological responses due to a variety of changes taking place in the ecosystem. Geographers (mainly soil and climate researchers) directly measure physical 
and chemical parameters of the environment (e.g. moisture, temperature, salinity, acidity, organic carbon content). Abiotic parameters can be related to conditions at the time of sampling, unlike bioindicators which serve a temporal element, integrating past and presence conditions. Faunistic indicators are invaluable and sensitive tools. They can be used between sites and can detect and estimate subtle differences which are difficult to measure by classical geographical methods. An example would be, in arable land where contaminants as a result of management, can occur in very low concentrations. Moreover, faunistic indicators can be helpful in making an indirect estimation of the landscape structure organisation between sites in terms of biodiversity maintenance.

\section{Conclusions}

There is a very wide range of possibilities for applying Carabidae and Araneae as indicators in geographical studies, both in terms of the range of possibilities of the study location choice (arable, forest, suburban landscape etc.), and the subject matter of study. Nowadays geographers have considerably broadened the field of interest. Today's geographers perceive the landscape as a system with associated and interdependent components. Faunistic indicators can enrich geographical researchers with the quantitative

\section{References}

Aleksandrowicz O., Pakuta B., Mazur J., 2008. Biegaczowate (Coleoptera: Carabidae) w uprawie pszenicy w okolicy Lęborka. Słupskie Prace Biologiczne, no. 5, pp. 15-25.

Angold P.G., Sadler J.P., Hill M.O., Pullin A., Rushton S., Austin K., Small E., Wood B., Wadsworth R., Sanderson R., Thompson K., 2006. Biodiversity in urban habitat patches. Science of the Total Environment, vol. 360, no. 1-3, pp. 196-204. and qualitative data that allow for an estimation of an ecological response due to the variety of changes taking place in the ecosystem. Faunistic indicators are invaluable tools for indirectly estimating subtle environmental changes which result in a specific interaction between ecosystem components. Such changes and interactions are difficult to measure by traditional methods. Faunistic indicators can be used to assess the impact of human activities in a more cost-effective way. The key methodological aspects are to choose the most accurate faunistic groups for a study along with using a standardised collection method. It is also important to consider the environmental parameters which have an impact on the selected bioindicators. Each method has its advantages and disadvantages. This method can be implemented by physical geographers or landscape ecologists in workshops but the method requires specialised knowledge. For this reason, this method can be applied in interdisciplinary studies with a larger group of experts.

\section{Acknowledgements}

I would like to give my special thanks to Dr. Jacek Wolski for the editorial revision of the manuscript. I would also like to acknowledge Professor Jerzy Solon for his comments.

Atlegrim O., Sjöberg K., Ball J.P., 1997. Forestry effects on a boreal ground beetle community in spring: Selective logging and clear-cutting compared. Entomologica Fennica, vol. 8, no. 1, pp. 19-26.

Beaudry S., Duchesne L.C., Côté B., 1997. Short-term effects of three forestry practices on carabid assemblages in a jack pine forest. Canadian Journal of Forest Research, vol. 27, no. 12, pp. 2065-2071.

Birkhofer K., Bezemer T.M., Bloem J., Bonkowski M., Christensen S., Dubois D., 
Ekelund F., Fliessbach A., Gunst L., Hedlund K., Mäder P., Mikola J., Robin Ch., Setälä H., Tatin-Froux F., Van der Putten W.H., SCHEU S., 2008. Long-term organic farming fosters below and aboveground biota: Implications for soil quality, biological control and productivity. Soil Biology and Biochemistry, vol. 40, no. 9, pp. 2297-2308.

BŁaszkiewicz M., Schwerk A., 2013. Carabid beetle (Coleoptera: Carabidae) diversity in agricultural and post-agricultural areas in relation to the surrounding habitats. Baltic Journal of Coleopterology, vol. 13, no. 1, pp. 15-26.

Brennan K.E.C., Ashby L., Majer J.D., Moir M.L., $\mathrm{KoCH}$ J.M., 2006. Simplifying assessment of forest management practices for invertebrates: How effective are higher taxon and habitat surrogates for spiders following prescribed burning? Forest Ecology and Management, vol. 231, no. 1-3, pp. 138-154.

Breure A.M., Mulder CH., Römbke J., Ruf A., 2005. Ecological classification and assessment concepts in soil protection. Ecotoxicology and Environmental Safety, vol. 62, no. 2, pp. 211-229.

Buddle C.M., LANGOR D.W., POHL G.R., SPENCE J.R., 2006. Arthropod responses to harvesting and wildfire: Implications for emulation of natural disturbance in forest management. Biological Conservation, vol. 128, no. 3, pp. 346-357.

Butterfield J., Luff M.L., Baines M., Eyre M.D., 1995. Carabid beetle communities as indicators of conservation potential in upland forests. Forest Ecology and Management, vol. 79, no. 1-2, pp. 63-77.

BÜCHS W., 2003. Biodiversity and agri-environmental indicators - general scopes and skills with special reference to the habitat level [in:] W. Büchs (ed.), Biotic Indicators for Biodiversity and Sustainable Agriculture. Agriculture, Ecosystems \& Environment, vol. 98, no. 1-3, pp. 35-78.

Büchs W., Harenberg A., Zimmermann J., WeIsS B., 2003. Biodiversity, the ultimate agri-environmental indicator? Potential and limits for the application of faunistic elements as gradual indicators in agroecosystems [in:] W. Büchs (ed.), Biotic Indicators for Biodiversity and Sustainable Agriculture. Agriculture, Ecosystems \& Environment, vol. 98, no. 1-3, pp. 99-123.
Callaham M.A., Richter D.D., Coleman D.C., Hofmockel M., 2006. Long-term land-use effects on soil invertebrate communities in Southern Piedmont soils, USA [in:] T. Decaens, P. Lavelle, M. Aubert, S. Barot, F. Bureau, P. Margerie, P. Mora, J.-P. Rossi (eds.), ICSZ - Soil Animals and Ecosystems Services. European Journal of Soil Biology, vol. 42, suppl. 1, pp. 150-156.

Cameron A., Johnston R.J., McAdam J., 2004. Classification and evaluation of spider (Araneae) assemblages on environmentally sensitive areas in Northern Ireland. Agriculture, Ecosystems \& Environment, vol. 102, no. 1, pp. 29-40.

Cárdenas A.M., Hidalgo J.M., 2007. Application of the mean individual biomass (MIB) of ground beetles (Coleoptera, Carabidae) to assess the recovery process of the Guadiamar Green Corridor (southern Iberian Peninsula). Biodiversity and Conservation, vol. 16, no. 14, pp. 4131-4146.

Cardoso P., Silva I., de Oliveira N.G., SerraNO A.R.M., 2004. Indicator taxa of spider (Araneae) diversity and their efficiency in conservation. Biological Conservation, vol. 120, no. 4, pp. 517-524.

Cardooso P., Silva I., de Oliveira N.G., SerRANO A.R.M., 2007. Seasonality of spiders (Araneae) in Mediterranean ecosystems and its implications in the optimum sampling period. Ecological Entomology, vol. 32, no. 5, pp. 516-526.

ChURChILl T.B., 1998. Spiders as ecological indicators in the Australian tropics: family distribution patterns along rainfall and grazing gradients [in:] P.A. Selden (ed.), Proceedings of the 17th European Colloquium of Arachnology. Edinburgh: British Arachnological Society, pp. 325-330.

Cleland E.E., 2012. Biodiversity and Ecosystem Stability. Nature Education Knowledge, 3(10):14, http://www.nature.com/scitable/knowledge/ library/biodiversity-and-ecosystem-stability-17059965 [23 September 2015].

Cole L.J., McCracken D.I., Downie I.S., Dennis P., Foster G.N., Waterhouse T., MurPhy K.J., Griffin A.L., Kennedy M.P., 2005. Comparing the effects of farming practices on ground beetle (Coleoptera: Carabidae) and spider (Araneae) assemblages of Scottish 
farmland. Biodiversity and Conservation, vol. 14, no. 2, pp. 441-460.

Cuesta D., Taboada A., Calvo L., Salgado J.M., 2008. Short-and medium-term effects of experimental nitrogen fertilization on arthropods associated with Calluna vulgaris heathlands in north-west Spain. Environmental Pollution, vol. 152, no. 2, pp. 394-402.

Davies K.F., Margules C.R., 1998. Effects of habitat fragmentation on carabid beetles: experimental evidence. Journal of Animal Ecology, vol. 67, no. 3, pp. 460-471.

Debras J.-F., Senoussi R., Rieux R., Buisson E., Dutolt T., 2008. Spatial distribution of an arthropod community in a pear orchard (southern France): Identification of a hedge effect. Agriculture, Ecosystems \& Environment, vol. 127, no. 3-4, pp. 166-176.

Deichsel R., 2006. Species change in an urban setting - ground and rove beetles (Coleoptera: Carabidae and Staphylinidae) in Berlin. Urban Ecosystems, vol. 9, no. 3, pp. 161-178.

Desender K., Maelfait J.-P., 1999. Diversity and conservation of terrestrial arthropods in tidal marshem along the River Schelde: a gradient analysis. Biological Conservation, vol. 87, no. 2 , pp. 221-229.

Diekötter T., Billeter R., Crist T.O., 2008. Effects of landscape connectivity on the spatial distribution of insect diversity in agricultural mosaic landscapes. Basic and Applied Ecology, vol. 9, no. 3, pp. 298-307.

DMOWSKA E., 2007. Nematode communities along the transect shelterbelt-ecotone-crop field. Polish Journal of Ecology, vol. 55, no. 4, pp. 665-680.

Driscoll D.A., WeIR T., 2005. Beetle responses to habitat fragmentation depend on ecological traits, habitat condition, and remnant size. Conservation Biology, vol. 19, no. 1, pp. 182-194.

DueluI P., OBRIST M.K., 1998. In search of the best correlates for local organismal biodiversity in cultivated areas. Biodiversity and Conservation, vol. 7, no. 3, pp. 297-309.

Elek Z., LÖVEl G.L., 2007. Patterns in ground beetle (Coleoptera: Carabidae) assemblages along an urbanisation gradient in Denmark. Acta Oecologica, vol. 32, no. 1, pp. 104-111.

Everts J.W., Aukema B., Hengeveld R., KoeMAN J.H., 1989. Side-effects of pesticides on ground-dwelling predatory arthropods in arable ecosystems. Environmental Pollution, vol. 59, no. 3, pp. 203-225.

Eyre M.D., Luff M.L., Rushton S.P., Topping C.J., 1989. Ground beetles and weevils (Carabidae and Curculionoidea) as indicators of grassland management practices. Journal of Applied Entomology, vol. 107, no. 1-5, pp. 508-517.

Feest A., Cardoso P., 2012. The comparison of site spider "biodiversity quality" in Portuguese protected areas. Ecological Indicators, vol. 14, no. 1, pp. 229-235.

Frampton G.K., van den Brink P.J., 2007. Collembola and macroarthropod community responses to carbamate, organophosphate and synthetic pyrethroid insecticides: Direct and indirect effects. Environmental Pollution, vol. 147, no. 1, pp. 14-25

Frank T., Kehrli P., Germann C., 2007. Density and nutritional condition of carabid beetles in wildflower areas of different age. Agriculture, Ecosystems \& Environment, vol. 120, no. 2-4, pp. 377-383.

GandhI K.J.K., Gilmore D.W., Katovich S.A., MatTson W.J., Zasada J.C., Seybold S.J., 2008. Catastrophic windstorm and fuel-reduction treatments alter ground beetle (Coleoptera: Carabidae) assemblages in a North American sub-boreal forest. Forest Ecology and Management, vol. 256, no. 5, pp. 1104-1123.

Gibson C.W.D., Hambler C., Brown V.K., 1992. Changes in spider (Araneae) assemblages in relation to succession and grazing management. Journal of Applied Ecology, vol. 29, no. 1, pp. 132-142.

Grandchamp A.-C., Bergamini A., Stofer S., Niemelä J., Duelli P., SCheidegger C., 2005. The influence of grassland management on ground beetles (Carabidae, Coleoptera) in Swiss montane meadows. Agriculture, Ecosystems \& Environment, vol. 110, no. 3-4, pp. 307-317.

Gravesen E., 2000. Spiders (Araneae) and other invertebrate groups as ecological indicators in wetland areas [in:] P. Gajdoš, S. Pekár (eds.), Proceedings of the 18th European Colloquium of Arachnology, Stará Lesná, Ekológia (Bratislava), vol. 19, suppl. 4, pp. 39-42.

Grimbacher P.S., Catterall C.P., 2007. How much do site age, habitat structure and spatial isolation influence the restoration of rainforest beetle 
species assemblages? Biological Conservation, vol. 135, no. 1, pp. 107-118.

GudleIFsson B.E., 2005. Beetle species (Coleoptera) in hayfields and pastures in northern Iceland. Agriculture, Ecosystems \& Environment, vol. 109, no. 3-4, pp. 181-186.

Hartley W., Uffindell L., Plumb A., Rawlinson H.A., Putwain P., Dickinson N.M., 2008. Assessing biological indicators for remediated anthropogenic urban soils. Science of the Total Environment, vol. 405, no. 1-3, pp. 358-369.

Heyer W., Hülsbergen K.J., Wittmann CH., Papaja S., Christen O., 2003. Field related organisms as possible indicators for evaluation of land use intensity [in:] W. Büchs (ed.), Biotic Indicators for Biodiversity and Sustainable Agriculture, Agriculture, Ecosystems \& Environment, vol. 98, no. 1-3, pp. 453-461.

Hole D.G., Perkins A.J., Wilson J.D., Alexander I.H., Grice P.V., Evans A.D., 2005. Does organic farming benefit biodiversity? Biological Conservation, vol. 122, no. 2, pp. 113-130.

HURUK S., 2005. Analysis of structures of carabid (Coleoptera, Carabidae) communities from meadows, crops and wasteland on chernozem soil around the village of Telatyn in Roztocze. Acta Biologica Universitatis Daugavpiliensis, vol. 5, no. 1, pp. 11-22.

HURUK S., 2007. Dynamika łowności Harpalus rufipes De Geer (Coleoptera: Carabidae) w jednorocznych uprawach rolnych $w$ zależności od typu gleby. Wiadomości Entomologiczne, vol. 26, no. 3, pp. 135-152.

Irmler U., Heller K., Meyer H., Reinke H.-D., 2002. Zonation of ground beetles (Coleoptera: Carabidae) and spiders (Araneida) in salt marshes at the North and the Baltic Sea and the impact of the predicted sea level increase. Biodiversity and Conservation, vol. 11, no. 7, pp. 1129-1147.

IVASK M., KuU A., Sizov E., 2007. Abundance of earthworm species in Estonian arable soils. European Journal of Soil Biology, vol. 43, suppl. 1, pp. 39-42.

Jelaska L.Š., Blanuša M., Durbešlć P., JelasKA S.D., 2007. Heavy metal concentrations in ground beetles, leaf litter, and soil of a forest ecosystem. Ecotoxicology and Environmental Safety, vol. 66, no. 1, pp. 74-81.

Jung M.-P., KIM S.-T., KIM H., LeE J.-H., 2008. Biodiversity and community structure of ground-dwelling spiders in four different field margin types of agricultural landscapes in Korea. Applied Soil Ecology, vol. 38, no. 2, pp. 185-195.

Kajak A., Kupryjanowicz J., Petrov P., 2000. Long term changes in spider (Araneae) communities in natural and drained fens in the Biebrza River Valley [in:] P. Gajdoš, S. Pekár (eds.), Proceedings of the 18th European Colloquium of Arachnology, Stará Lesná, Ekológia (Bratislava), vol. 19, suppl. 4, pp. 55-64.

Kajak A., Oleszczuk M., 2004. Effect of shelterbelts on adjoining cultivated fields: Patrolling intensity of carabid beetles (Carabidae) and spiders (Araneae). Polish Journal of Ecology, vol. 52, no. 2, pp. 155-172.

KoIVULA M., 2011. Useful model organisms, indicators, or both? Ground beetles (Coleoptera, Carabidae) reflecting environmental conditions. ZooKeys, vol. 100, pp. 287-317.

Kosewska A., Nietupski M., Laszczak-Dawid A., CiepielewSKA D., 2011. Naziemna fauna biegaczowatych (Col., Carabidae) występujaca w uprawach rzepaku ozimego. Progress in Plant Protection/Postępy w Ochronie Roślin, vol. 51, no. 2, pp. 763-770.

Kovács-Hostyánszki A., Elek Z., Balázs K., Centeri C., Falusi E., Jeanneret P., Penksza K., PodMANICZKY L., SZALKOVSZKI O., BÁldI A., 2013. Earthworms, spiders and bees as indicators of habitat quality and management in a low-input farming region - A whole farm approach. Ecological Indicators, vol. 33, pp. 111-120.

Kromp B., 1990. Carabid beetles (Coleoptera, Carabidae) as bioindicators in biological and conventional farming in Austrian potato fields. Biology and Fertility of Soils, vol. 9, no. 2, pp. 182-187.

Larrivèe M., Drapeau P., Fahrig L., 2008. Edge effects created by wildfire and clear-cutting on boreal forest ground-dwelling spiders. Forest Ecology and Management, vol. 255, no. 5-6, pp. 1434-1445.

ŁĘGOWSKI D., 2000. Przykłady wykorzystania pająów (Aranei) jako bioindykatorów zmian zachodzacych w środowiskach leśnych. Sylwan, vol. 144, no. 6, pp. 53-62.

ŁęGOWskı D., 2001. Waloryzacja Puszczy Białowieskiej metoda zooindykacyjna na podstawie pająów [in:] A. Szujecki (ed.), Próba szacunkowej waloryzacji lasów Puszczy Białowieskiej 
metoda zooindykacyjna. Warszawa: Wydawnictwo SGGW, pp. 207-234.

Maelfait J.-P., HendrickX F., 1997. Spiders as bio-indicators of anthropogenic stress in natural and seminatural habitats in Flanders (Belgium): some recent developments [in:] P.A. Selden (ed.), Proceedings of the 17th European Colloquium of Arachnology. Edinburgh: British Arachnological Society, pp. 293-300.

Magura T., 2002. Carabids and forest edge: spatial pattern and edge effect. Forest Ecology and Management, vol. 157, no. 1-3, pp. 23-37.

Magura T., TÓthmérész B., Molnár T., 2001. Forest edge and diversity: carabids along forest-grassland transects. Biodiversity and Conservation, vol. 10, no. 2, pp. 287-300.

Malumbres-Olarte J., Barratt B.I.P., Vink C.J., Paterson A.M., Cruickshank R.H., FerguSON C.M., BARTON D.M., 2013. Habitat specificity, dispersal and burning season: Recovery indicators in New Zealand native grassland communities. Biological Conservation, vol. 160, pp. 140-149.

Marc P., Canard A., YSnel F., 1999. Spiders (Araneae) useful for pest limitation and bioindication. Agriculture, Ecosystems \& Environment, vol. 74, no. 1-3, pp. 229-273.

Matveinen-Huju K., Koivula M., Niemelä J., RauHA A.M., 2009. Short-term effects of retention felling at mire sites on boreal spiders and carabid beetles. Forest Ecology and Management, vol. 258, no. 11, pp. 2388-2398.

MĄdRZEJowsKa K., SkŁOdOWSKI J., 2008. Assemblages of carabid beetles (Coleoptera: Carabidae) as zoo-indicator of water tourism impact on forest - lake ecotones. Baltic Journal of Coleopterology, vol. 8, no. 1, pp. 1-14.

McGeOCH M.A., 1998. The selection, testing and application of terrestrial insects as bioindicators. Biological Reviews, vol. 73, no. 2, pp. 181-201.

Moretti M., Conedera M., Duelli P., Edwards P.J., 2002. The effects of wild re on ground-active spiders in deciduous forests on the Swiss southern slope of the Alps. Journal of Applied Ecology, vol. 39, no. 2, pp. 321-336.

Møller A.P., Mousseau T.A., 2011. Efficiency of bio-indicators for low-level radiation under field conditions. Ecological Indicators, vol. 11, no. 2, pp. 424-430.
Nahmani J., Lavelle P., Rossi J.-P., 2006. Does changing the taxonomical resolution alter the value of soil macroinvertebrates as bioindicators of metal pollution? Soil Biology and Biochemistry, vol. 38, no. 2, pp. 385-396.

Niemelä J., Langor D., Spence J.R., 1993. Effects of clear-cut harvesting on boreal ground-beetle assemblages (Coleoptera: Carabidae) in western Canada. Conservation Biology, vol. 7, no. 3, pp. 551-561.

Olechowicz E., 2004. Soil-litter macrofauna in the mixed forest and midfield shelterbelts of different age (Turew area, West Poland). Polish Journal of Ecology, vol. 52, no. 4, pp. 405-419.

Opatovsky I., Pluess T., Schmidt-Entling M.H., Gavish-Regev E., Lubin Y., 2010. Are spider assemblages in fragmented, semi-desert habitat affected by increasing cover of agricultural crops? Agriculture, Ecosystems \& Environment, vol. 135, no. 4, pp. 233-237.

Otter R.R., Hayden M., Mathews T., Fortner A., BAILEY F.C., 2013. The use of tetragnathid spiders as bioindicators of metal exposure at a coal ASH spill site. Environmental Toxicology and Chemistry, vol. 32, no. 9, pp. 2065-2068.

Oxbrough A.G., Gittings T., O’Halloran J., Giller P.S., Kelly T.C., 2006. The initial effects of afforestation on the ground-dwelling spider fauna of Irish peatlands and grasslands. Forest Ecology and Management, vol. 237, no. 1-3, pp. 478-491.

Oxbrough A.G., Gittings T., O'Halloran J., GillER P.S., SMITH G.F., 2005. Structural indicators of spider communities across the forest plantation cycle. Forest Ecology and Management, vol. 212, no. 1-3, pp. 171-183.

Paoletti M.G., 1999. Using bioindicators based on biodiversity to assess landscape sustainability [in:] M.G. Paoletti (ed.), Invertebrate Biodiversity as Bioindicators of Sustainable Landscapes, Agriculture. Ecosystems \& Environment, vol. 74, no. 1-3, pp. 1-18.

Paquin P., 2008. Carabid beetle (Coleoptera: Carabidae) diversity in the black spruce succession of eastern Canada. Biological Conservation, vol. 141, no. 1, pp. 261-275.

Pardo T.M., Esteve M.A., Giménez A., Martínez-Fernández J., Carreño M.F., Serrano J., MiñAno J., 2008. Assessment of hydrological alterations on wandering beetle assemblages (coleoptera: Carabidae and Tenebrionidae) in 
coastal wetlands of arid Mediterranean systems. Journal of Arid Environments, vol. 72, no. 10, pp. 1803-1810.

Pearce J.L., Venier L.A., 2006. The use of ground beetles (Coleoptera: Carabidae) and spiders (Araneae) as bioindicators of sustainable forest management: A review. Ecological Indicators, vol. 6, no. 4, pp. 780-793.

Pearce J.L., Venier L.A., Eccles G., Pedlar J., MCKenneY D., 2005. Habitat islands, forest edge and spring-active invertebrate assemblages. Biodiversity and Conservation, vol. 14, no. 12, pp. 2949-2969.

Pérès G., Vandenbulcke F., Guernion M., Hedde M., Beguiristain T., Douay F., Houot S., Piron D., Richard A., Bispo A., Grand C., Galsomies L., Cluzeau D., 2011. Earthworm indicators as tools for soil monitoring, characterization and risk assessment. An example from the national Bioindicator programme (France). Pedobiologia, vol. 54, suppl., pp. 77-87.

Perner J., Malt S., 2003. Assessment of changing agricultural land use: response of vegetation, ground-dwelling spiders and beetles to the conservation of arable land into grassland [in:] W. Büchs (ed.), Biotic indicators for biodiversity and sustainable agriculture. Agriculture, Ecosystems \& Environment, vol. 98, no. 1-3, pp. 169-181.

Pétillon J., Georges A., Canard A., Lefeuvre J.-C., BAKKER J.P., YSNEL F., 2008. Influence of abiotic factors on spider and ground beetle communities in different salt-marsh systems. Basic and Applied Ecology, vol. 9 , no. 6, pp. 743-751.

PIDWIRny M., 2006. Introduction to Geography. Fundamentals of Physical Geography, http:// www.physicalgeography.net/fundamentals/1a. html [23 September 2015].

Pihlaja M., Koivula M., Niemelä J., 2006. Responses of boreal carabid beetle assemblages (Coleoptera, Carabidae) to clear-cutting and top-soil preparation. Forest Ecology and Management, vol. 222, no. 1-3, pp. 182-190.

Pinzon J., Spence J.R., Langor D.W., 2012. Responses of ground-dwelling spiders (Araneae) to variable retention harvesting practices in the boreal forest. Forest Ecology and Management, vol. 266, pp. 42-53.

Pohl G.R., Langor D.W., Spence J.R., 2007. Rove beetles and ground beetles (Coleoptera: Staphylinidae, Carabidae) as indicators of harvest and regeneration practices in western Canadian foothills forests. Biological Conservation, vol. 137, no. 2, pp. 294-307.

Postma-Blaaum M.B., de Goede R.G.M., Bloem J., Faber J.H., BrussaArd L., 2010. Soil biota community structure and abundance under agricultural intensification and extensification. Ecology, vol. 91, no. 2, pp. 460-473.

Postma-Blaaum M.B., de Goede R.G.M., Bloem J., Faber J.H., BrussaArd L., 2012. Agricultural intensification and de-intensification differentially affect taxonomic diversity of predatory mites, earthworms, enchytraeids, nematodes and bacteria. Applied Soil Ecology, vol. 57, pp. 39-49.

Price G.W., Voroney R.P., 2008. Response to annual applications of de-inked papermill biosolids by field earthworms on three agricultural soils. Applied Soil Ecology, vol. 38, no. 3, pp. 230-238.

Project Bıo-Bıo, 2013. Indicators for Biodiversity in Organic and Low Input Farming Systems. http://www.biobio-indicator.org [23 September 2015].

Rainio J., Niemelä J., 2003. Ground beetles (Coleoptera: Carabidae) as bioindicators. Biodiversity and Conservation, vol. 12, no. 3, pp. 487-506.

RegulsKa E., 2011. Carabidae in landscape research on the basis of literature, 2005-08. Polish Journal of Environmental Studies, vol. 20, no. 3, pp. 733-741.

RICHLING A., 1983. Subject of study in complex physical geography (Landscape geography). GeoJournal, vol. 7, no 2, pp. 185-187.

Richling A., Solon J., 2011. Ekologia krajobrazu. Warszawa: PWN.

Roarty S., Schmidt O., 2013. Permanent and new arable field margins support large earthworm communities but do not increase in-field populations. Agriculture, Ecosystems \& Environment, vol. 170, pp. 45-55.

Roo-Zielińska E., Solon J., Degórski M., 2007. Ocena stanu i przekształceń środowiska przyrodniczego na podstawie wskaźników geobotanicznych, krajobrazowych i glebowych (podstawy teoretyczne i przykłady zastosowań). Monografie, 9, Warszawa: Instytut Geografii i Przestrzennego Zagospodarowania PAN. 
RömbKe J., BREURE J., 2005. Status and outlook of ecological soil classification and assessment concepts. Ecotoxicology and Environmental Safety, vol. 62, no. 2, pp. 300-308.

Rushton S.P., Luff M.L., Eyre M.D., 1989. Effect of pasture improvement and management on the ground beetle and spider communities of upland grasslands. Journal of Applied Ecology, vol. 26, no. 2, pp. 489-503.

SCHIKORA H.-B., 1994. Changes in the terrestrial spider fauna (Arachnida: Araneae) of a North German raised bog disturbed by human influence. 1964-1965 and 1986-1987: A comparison. Memoirs of the Entomological Society of Canada, vol. 126, suppl. 169, pp. 61-71.

Schipper A.M., Wijnhoven S., Leuven R.S.E.W., Ragas A.M.J., HendriKs A.J., 2008. Spatial distribution and internal metal concentrations of terrestrial arthropods in a moderately contaminated lowland floodplain along the Rhine River. Environmental Pollution, vol. 151, no. 1, pp. 17-26.

Schweiger O., Maelfait J.P., van Wingerden W., Hendrickx F., Billeter R., Speelmans M., Augenstein I., Aukema B., Aviron S., Bailey D., Bukacek R., Burel F., Diekötter T., Dirksen J., Frenzel M., Herzog F., Lirra J., Roubalova M., Bugter R., 2005. Quantifying the impact of environmental factors on arthropod communities in agricultural landscapes across organizational levels and spatial scales. Journal of Applied Ecology, vol. 42, no. 6, pp. 1129-1139.

Sepp K., Ivask M., Kaasik A., MikK M., PeepSON A., 2005. Soil biota indicators for monitoring the Estonian agri-environmental programme [in:] F. Herzog (ed.), Agri-Environmental Schemes as Landscape Experiments. Agriculture, Ecosystems \& Environment, vol. 108, no. 3, pp. 264-273.

SkŁODOWSKI J., 1995. Antropogeniczne przeobrażenia zespołów biegaczowatych (Col. Carabidae) $w$ ekosystemach borów sosnowych Polski [in:] A. Szujecki, J.W. Skłodowski, A. Wojciechowska (eds.), Antropogeniczne przeobrażenia epigeicznej i glebowej entomofauny borów sosnowych. Warszawa: Fundacja "Rozwój SGGW", pp. 17-174.

SKŁODOWSKI J., 1997. Interpretacja stanu środowiska leśnego za pomoca modelu SCP/SBO zgrupowań biegaczowatych (Col. Carabidae) [in:] S. Mazur, J.W. Skłodowski, A. Wojciechow- ska (eds.), Waloryzacja ekosystemów leśnych metodami zooindykacyjnymi. VI Sympozjum Ochrony Ekosystemów Leśnych, Jedlnia 2-3 grudnia 1996 r., Warszawa: Fundacja "Rozwój SGGW", pp. 69-87.

SkŁOdowski J., GarbalińsKa P., 2011. Ground beetle (Coleoptera, Carabidae) assemblages inhabiting Scots pine stands of Puszcza Piska Forest: six-year responses to a tornado impact. ZooKeys, vol. 100, pp. 371-392.

Stańska M., Hajdamowicz I., ŻabKa M., 2002. Epigeic spiders of alder swamp forests in Eastern Poland [in:] S. Toft, N. Scharff (eds.), Proceedings of the 19th European Colloquium of Arachnology, Århus 17-22 July 2000, European Arachnology 2000, Aarhus: Aarhus University Press, pp. 191-197.

SzUjeCKI A., 2001. Waloryzacja lasów Puszczy Białowieskiej metoda zooindykacyjnq - synteza wyników [in:] A. Szujecki (ed.), Próba szacunkowej waloryzacji lasów Puszczy Białowieskiej metoda zooindykacyjna. Warszawa: Wydawnictwo SGGW, pp. 395-411.

Szujecki A., Szyszko J., Mazur S., Perliński S., 1983. The process of forest soil macrofauna formation after afforestation of farmland. Warsaw: Warsaw Agricultural University Press.

SZYSZKO J., 1997. Próba waloryzacji środowisk leśnych przy pomocy biegaczowatych (Carabidae, Col.) [in:] S. Mazur, J.W. Skłodowski, A. Wojciechowska (eds.), Waloryzacja ekosystemów leśnych metodami zooindykacyjnymi. VI Sympozjum Ochrony Ekosystemów Leśnych, Jedlnia 2-3 grudnia 1996 r., Warszawa: Fundacja "Rozwój SGGW", pp. 42-60.

SzYszko J., SChwerk A., MalczYK J., 2011. Animals as an indicator of carbon sequestration and valuable landscapes. ZooKeys, vol. 100, pp. 565-573.

Taboada A., Kotze D.J., Tárrega R., Salado J.M., 2006. Traditional forest management: Do carabid beetles respond to human-created vegetation structures in an oak mosaic landscape? Forest Ecology and Management, vol. 237, no. 1-3, pp. 436-449.

Taboada A., Kotze D.J., Tárrega R., Salado J.M., 2008. Carabids of differently aged reforested pinewoods and a natural pine forest in a historically modified landscape. Basic and Applied Ecology, vol. 9, no. 2, pp. 161-171. 
Thomson L.J., Hoffmann A.A., 2006. Field validation of laboratory-derived IOBC toxicity ratings for natural enemies in commercial vineyards. Biological Control, vol. 39, no. 3, pp. 507-515.

Vandewalle M., de Bello F., Berg M.P., Bolger T., Dolédec S., Dubs F., Feld C.K., Harrington R., Harrison P.A., LaVorel S., da Silva P.M., Morettı M., Niemelä J., Santos P., Sattler T., Sousa J.P., Sykes M.T., Vanbergen A.J., Woodcock B.A., 2010. Functional traits as indicators of biodiversity response to land use changes across ecosystems and organisms. Biodiversity and Conservation, vol. 19, no. 10, pp. 2921-2947.

Watts C.H., Clarkson B.R., Didham R.K., 2008. Rapid beetle community convergence following experimental habitat restoration in a mined peat bog. Biological Conservation, vol. 141, no. 2, pp. 568-579.

Werner S.M., RafFA K.F., 2000. Effects of forest management practices on the diversity of ground-occurring beetles in mixed northern hardwood forests of the Great Lakes Region. Forest Ecology and Management, vol. 139, no. 1-3, pp. 135-155.
Wickings K., Grandy A.S., 2013. Management intensity interacts with litter chemistry and climate to drive temporal patterns in arthropod communities during decomposition. Pedobiologia, vol. 56, no. 2, pp. 105-112.

WiezIK M., Svitok M., DovČIAK M., 2007. Conifer introductions decrease richness and alter composition of litter-dwelling beetles (Coleoptera) in Carpathian oak forests. Forest Ecology and Management, vol. 247, no. 1-3, pp. 61-71.

Woodcock B.A., Westbury D.B., Potts S.G., HarRIS S.J., BROWN V.K., 2005. Establishing field margins to promote beetle conservation in arable farms. Agriculture, Ecosystems \& Environment, vol. 107, no. 2-3, pp. 255-266.

Yu X.-D., Luo T.-H., Zhou H.-Z., 2006. Distribution of carabid beetles among regenerating and natural forest types in Southwestern China. Forest Ecology and Management, vol. 231, no. 1-3, pp. 169-177.
(C) Edyta Regulska

(C) Geographia Polonica

(C) Institute of Geography and Spatial Organization

Polish Academy of Sciences - Warsaw • 2015
Article first received • January 2014 Article accepted • May 2014 
http://rcin.org.pl 